\title{
Therapeutic hypothermia in brain trauma injury: controversies
}

\author{
Hernando Raphael Alvis-Miranda ${ }^{1}$, Gabriel Alcala-Cerra ${ }^{2}$, Andres \\ M. Rubiano ${ }^{3}$, Omar Ramirez ${ }^{4}$, Luis Rafael Moscote-Salazar ${ }^{2}$ \\ ${ }^{1}$ Physician, Universidad de Cartagena, Colombia \\ ${ }^{2}$ Neurosurgeon, Universidad de Cartagena, Colombia \\ ${ }^{3}$ Neurosurgeon, Southcolombian University, Neurosurgery and Critical Care, Neiva University \\ Hospital, Huila, Colombia, Meditech Foundation \\ ${ }^{4}$ Neurosurgeon, Universidad el Bosque, Bogota, Colombia
}

\begin{abstract}
Traumatic brain injury (TBI) is a common cause of death and disability in developed countries. It is a major cause of mortality in young patients worldwide. Intracranial hypertension is the cause of death in more than $80 \%$ of patients with TBI. When secondary lesions occur, start a number of mechanisms that increase the metabolic injury to brain tissue. Induction of hypothermia has been shown to alter the natural course of the disease process. The biological foundations suggest that hypothermia may have a potential benefit, although some publications have shown no improvement, it is clear that in a group of mostly young patients, early hypothermia may be beneficial. We present a practical review of the literature on this subject.
\end{abstract}

Key words: Hypothermia, traumatic brain injury, intracranial hypertension.

\section{Introduction}

Morbidity and mortality from traumatic injuries are globally recognized as a severe health problem in constant development, these injuries are among the leading causes of death, occurs in all regions, affecting people of all ages and socioeconomic status. (1) Traumatic brain injury (TBI) is a worldwide health problem, (2) according to predictions, the neurotrauma will remain representing a growing number of deaths worldwide by 2020 . (3)

Among the TBI secondary lesions are increased intracranial pressure ( $\mathrm{ICH}$ ), release of proinflammatory mediators and free radicals, decreased cerebral blood flow due to systemic hypotension and hypoxia, which are all recognized risk factors for poor outcome. (4-6)

A potential therapy that improves outcomes in specific patient populations is therapeutic hypothermia (TH). (7-11) Hypothermia has been used therapeutically for centuries, $(12,13)$ and has been studied extensively in TBI, (14-26) as a strategy to 
improve post-traumatic neurologic outcomes, (2) yet it is one of the few topics that has caused such debate and lack of consensus about its role in this type of injury. (27)

Although there is much information about the pathophysiology of TBI, $(28,29)$ has not yet reached the successful handover of therapeutic interventions seen as promising in animal models to clinical practice. (30) HT is currently recommended by the American Heart Association (AHA), as neuroprotective therapy in the post cardiac arrest care. $(13,31)$ Theoretically it is indicated for the treatment of complications associated with TBI such as ICH (>20mm Hg) and status epilepticus, (32) but is not considered as first-line treatment for TBI in USA, however, it is in use for TBI in $47 \%$ of neurotrauma centers in Japan. (33) The aim of this paper is to briefly review some key aspects regarding therapeutic HT in the context of TBI.

\section{Definition}

HT is a treatment modality conducted by the physician in order to reduce the core temperature. (13) Hypothermia is defined as a body temperature below $35^{\circ} \mathrm{C}\left(95^{\circ} \mathrm{F}\right)$. It can be classified by their intensity in five groups: (34)

- $\quad$ Mild: 32 a $34^{\circ} \mathrm{C}$

- Moderate: 28 a $31.9^{\circ} \mathrm{C}$

- Intense: 11 a $28^{\circ} \mathrm{C}$.

- Deep: $6-10^{\circ} \mathrm{C}$

- Ultradeep: $\leq 5^{\circ} \mathrm{C}$

\section{History}

The use of HT was described by the ancient Egyptians, Greeks and Romans. Hippocrates advised covered with ice and snow in poorly healing wounds to reduce blood loss. Galen also described some uses of HT.

In the 50s, several studies on the physiological effects of HT in humans were conducted, until now no randomized clinical trial. In 1972, Robert Boyle and James Curie and later William Osler attempted to use HT in the treatment of typhoid fever, immersing the patient in icy sea water and brine. Osler reported a $17 \%$ reduction in deaths of patients at Johns Hopkins Hospital. (34) In 1814, Napoleon Bonaparte's General Surgeon, Baron Larrey, described the wounded soldiers were placed near the fires died first than those who were not reheated. (35) The first attempt was made in November 28,1938 . $(36,37)$

The potential beneficial effect of HT in the treatment of TBI has been reported since mid1940. (37) During World War II, the Nazis conducted studies on Jewish men to simulate the conditions suffered by the army and the fallen pilots during wartime, with the objectives to determine the cause of death from hypothermia (cardiac or metabolic), to establish the exact temperature at which the death occurred, determine the best methods of resuscitation, and the most appropriate type of protective clothing. (38-40)

Posteriorly, with the works of Bigelow, the intraoperative HT was used since 1950. (41) Perhaps the most important lesson of the HT history is that it not only seeks to reduce metabolism, but also that mild HT is sufficient, that intensive care in these patients is always necessary, and that the implementation of strategies is needed. 
DOI: 10.2478/romneu-2014-0035

\section{Mechanism of action}

To facilitate the use of HT in specific TBI populations is important not only understanding the mechanisms of secondary damage in which the HT mediate, but also the potentially repair mechanisms that can be regulated by hypothermia. $(42,43) \mathrm{HT}$ reduces histopathological damage resulting from the brain injury, to mediate multiple and specific mechanisms of secondary injury as consequence of TBI, such as ICH, $(10,14,32$, 44-46) but the exact mechanisms by which HT has beneficial effects are unknown.

Before 1990 it was felt that the HTmediated neuroprotection was due to reduced cerebral metabolism. (14) Although such reduction does exist, there are other neuroprotective mechanisms. Decreasing core temperature, so does the metabolic rate, and in turn the consumption of oxygen and glucose, also decreases the production of carbon dioxide, fact that by limiting oxygen delivery, may help to prevent or ameliorate injury. (47) Electrolyte levels are affected due to tubular dysfunction or fluid movement between the intracellular and extracellular spaces.

Although the HT appears to block apoptotic pathways in early stages, there is a small therapeutic window through which the HT can affect this process. (48) HT also reduces or ameliorates the lesion produced by the excitatory neurotransmission. Experimental evidence suggests that the HT decrease ICP through modulation of inflammatory reactions, by reducing cerebral metabolic rate, epileptic discharges and the generation of reactive oxygen species. (49-52) Unfortunately, such theoretical benefits remain as inconclusive in clinical studies. (2)

\section{Metodology to implement hypothermia}

There are three commonly recognized phases in the implementation of hypothermia: induction, maintenance and overheating. The purpose of the induction phase is to lower the temperature as fast as possible. In TBI, clinical evidence indicates that the temperature range associated with better outcomes appears to be $32-35^{\circ} \mathrm{C}$. (45) It is preferable to reach the maintenance phase quickly because the induction phase may be associated with immediate side effects such as electrolyte disorders, hyperglycemia, and tremor, (53) therefore continuous monitoring of ventilation, blood pressure, sedation, glucose and electrolytes is required.

There are several methods for the induction of TH: (53)

- Surface cooling with air: traditional methods such as skin exposure to air, which can be combined with sponge baths are effective, cooling blankets with airflow are also available.

- Surface cooling with fluids: here are included ice bags, pillows or blankets suits with cooling air circulation, also circulating water pads coated with hydrogel.

- Central Cooling: here are used ice-cold fluid infusions. More invasive devices such as intravascular catheters with balloons full of cold saline. Cold metal components and antipyretic drugs are also used.

Desired temperature is reached more quickly by combining methods. (53) 
In the maintenance phase, core temperature must be accurately controlled to maintain stability of the patient. Once at this stage, precautionary measures against side effects of HT should be taken, such as nosocomial infections, or pressure ulcers, especially if therapy is for prolonged time. Rewarming involves slow temperature increase to normal ranges, at a preferred rate of $0.25^{\circ} \mathrm{C}$ per hour. Should be slow to: (54)

- Minimize electrolyte abnormalities as consequence of movement of fluid between the intra-and extracellular compartments.

- $\quad$ Reduce insulin sensitivity and the risk of hypoglycemia in the case of receiving insulin the patient.

- Prevent exacerbation of injury mechanisms in the injured brain as consequence of the rapid warming.

- Minimizing vasodilation heating degree in order to maintain blood pressure and cerebral perfusion pressure.

Hyperthermia occurs quite commonly after rewarming phase. Normothermia must be maintained because fever is independently associated with adverse outcomes in various forms of brain injury. (53,55-57) Energy crisis and phospholipid degradation occur very easily after TBI in the perilesional tissue. It has been demonstrated by microdialysis studies in patients with severe TBI that mild HT protects perilesional tissues better than to normal brain tissue, to reduce lactate/glucose, lactate/pyruvate ratios and glycerol levels in such areas. (58) Apparently, a high temperature appears not to alter brain neurochemistry substrates and adequate oxygen delivery, (59) however, has been observed that in critically ill patients undergoing hypothermia have less glutamate and lactate/pyruvate ratios, indicating that hypothermia can also participate.

In an animal model of mild TBI was observed that hyperthermia at $39{ }^{\circ} \mathrm{C}$ for 15 minutes before the occurrence of injury exacerbates the lesion, causing that mild TBI were vulnerable to cerebrovascular and metabolic processes, such as increased extracellular glutamate concentration, intracellular levels of calcium in the bloodbrain barrier and increased inflammation. (60) Hypothermia reduces cerebral metabolism during stress, reduces the release of excitatory neurotransmitters, and reduces the permeability of the blood brain barrier. (61)

\section{Complications}

Hypothermia can lead to several complications, including increased risk of infections, electrolyte disturbances such as hypokalemia, hyperkalemia, increased bleeding time, thrombocytopenia, neutropenia, acute renal failure, sepsis, decreased pulse, decreased cardiac output, hypoventilation, CNS depression, hyporeflexia or areflexia, bradycardia, atrial fibrillation, acute pulmonary edema, ventricular fibrillation and asystole. Importantly, many of these complications occur only in cases of severe hypothermia, some have been documented in moderate hypothermia; therefore, the current recommendation is the use of mild hypothermia. 
DOI: 10.2478/romneu-2014-0035

\section{Evidence}

The neuroprotective effects of HT in isolated injuries, more often TBI or or spinal cord injury have yielded conflicting results (mortality and functional outcome) in clinical trials. $(62,63)$ A partial explanation for such conflicting results derived from the different methodological designs used in clinical trials, basically these studies can be divided into those in which the HT was used to treat ICH or studies in which HT was intended to act as neuroprotective therapy to mediate the cease of biochemical and inflammatory cascade, so that comparisons between the studies end controversial. (63)

Specifically in TBI, Harris et al., (64) in their meta-analysis about the role of HT in the management of severe TBI reported no benefit, indeed, Clifton et al., (65) reported a negative effect on the outcome of patients with the same severity of TBI. Polderman et al., (66) demonstrated the effectiveness of HT for the treatment of ICH in patients with severe TBI. In their meta-analysis, Peterson et al., (67) reported a statistically significant reduction in mortality and an increase in favorable neurological outcomes, the benefits were greater in HT maintained for more than 48 hours, however, the increased risk of developing pneumonia opaque favorable findings.

Hutchinson et al., (68) in its international multicenter study showed that in children with severe TBI, HT initiated within 8 hours after the offending event and that continued for 24 hours does not improve neurological outcome, and may even increase mortality. It has also been shown effective not selective cooling systems for achieving desired temperature gradients. (69) Findings like these generate controversy, especially because there are compelling evidence showing benefits of HT in animal models, $(14,70)$ and human clinical studies have shown the beneficial impact of HT to reduce intracranial pressure, one of the cornerstones in the treatment of TBI. $(27,71$, 72)

Georgiou et al., (73) in their meta-analysis on the effect of HT initiated immediately upon admission, mortality and neurologic outcomes in patients with TBI reported the association of HT with cerebrovascular disorders in rewarming, and did not identify benefits on mortality or neurologic morbidity. In a study of 37 patients with severe TBI admitted to ICU, Childs et al., (57) were monitored the behavior of the brain temperature regarding survival. The results support the widespread view that an early increase in temperature of patients with TBI may be associated with poor prognosis, but also suggest an increased risk of death when the temperature is consistently below the "normal" during the first $48 \mathrm{~h}$.

The randomized clinical trial 'National Acute Brain Injury Study: Hypothermia II' (NABIS II trial) (42) showed no beneficial effect on the early use of HT in patients with TBI, however an interesting point to consider is the fact that overheating was induced very early, probably increasing the ICP and then worsening outcomes. (23) Currently studies are underway, as the european trial 'EUROTHERM' (ISRCTN34555414), (74) the Prophylactic Hypothermia Trial to Lessen Traumatic Brain Injury (POLAR-RCT; NCT00987688). 
According to guidelines issued by the Brain Trauma Foundation /American Association of Neurological Surgeons, the optional and cautious use of HT in adults with TBI is a level III recommendation. (5)

\section{Conclusions}

Most of the evidence for the neuroprotective effects of mild to moderate HT derived from animal research models, their clinical role is still undefined, so human studies are needed to clarify its real therapeutic effect. (62)

\section{Correspondence}

Dr. Luis Rafael Moscote Salazar, Universidad de Cartagena, Cartagena de Indias, Colombia, SouthamericaE-mail: mineurocirujano@aol.com

\section{References}

1. Hyder AA, Aggarwal A. The increasing burden of injuries in Eastern Europe and Eurasia: making the case for safety investments. Health Policy (New York) [Internet]. 2009 Jan [cited 2013 Jan 26];89(1):1-13. Available from: http://www.ncbi.nlm.nih.gov/pubmed/18571277

2. Bukur M, Kurtovic S, Berry C, Tanios M, Ley EJ, Salim A. Pre-hospital hypothermia is not associated with increased survival after traumatic brain injury. J Surg Res [Internet]. 2012 Jun 1 [cited 2012 Nov 27];175(1):24-9. Available from:

http://www.ncbi.nlm.nih.gov/pubmed/21872881

3. Murray CJ, Lopez AD. Alternative projections of mortality and disability by cause 1990-2020: Global Burden of Disease Study. Lancet [Internet]. 1997 May 24 [cited 2012 Nov 7];349(9064):1498-504. Available from: http://www.ncbi.nlm.nih.gov/pubmed/9167458

4. Enriquez P, Bullock R. Molecular and cellular mechanisms in the pathophysiology of severe head injury. Curr Pharm Des [Internet]. 2004 Jan [cited 2013 Jan 26];10(18):2131-43. Available from: http://www.ncbi.nlm.nih.gov/pubmed/15281889
5. Bratton SL, Chestnut RM, Ghajar J, McConnell Hammond FF, Harris OA, Hartl R, et al. Guidelines for the management of severe traumatic brain injury. III. Prophylactic hypothermia. J Neurotrauma [Internet]. 2007 Jan [cited 2013 Jan 25];24 Suppl 1:S21-5. Available from: http://www.ncbi.nlm.nih.gov/pubmed/17511540 6. Sharma D, Vavilala MS. Perioperative management of adult traumatic brain injury. Anesth Clin [Internet]. 2012 Jun [cited 2012 Nov 17];30(2):333-46. Available from: http://www.ncbi.nlm.nih.gov/pubmed/22901613

7. Bernard SA, Gray TW, Buist MD, Jones BM, Silvester W, Gutteridge G, et al. Treatment of comatose survivors of out-of-hospital cardiac arrest with induced hypothermia. N Engl J Med [Internet]. 2002 Feb 21 [cited 2012 Nov 12];346(8):557-63. Available from: http://www.ncbi.nlm.nih.gov/pubmed/11856794

8. Eicher DJ, Wagner CL, Katikaneni LP, Hulsey TC, Bass WT, Kaufman DA, et al. Moderate hypothermia in neonatal encephalopathy: efficacy outcomes. Pediatr Neurol [Internet]. 2005 Jan [cited 2012 Nov 13];32(1):11$7 . \quad$ Available from: http://www.ncbi.nlm.nih.gov/pubmed/15607598 9. Holzer M, Bernard SA, Hachimi-Idrissi S, Roine RO, Sterz F, Müllner M. Hypothermia for neuroprotection after cardiac arrest: systematic review and individual patient data meta-analysis. Crit Care Med [Internet]. 2005 Feb [cited 2013 Jan 21];33(2):414-8. Available from: http://www.ncbi.nlm.nih.gov/pubmed/15699847

10. Marion D, Bullock MR. Current and future role of therapeutic hypothermia. J Neurotrauma [Internet]. 2009 Mar [cited 2013 Jan 26];26(3):455-67. Available from: http://www.ncbi.nlm.nih.gov/pubmed/19292697 11. Shankaran S, Laptook AR, Ehrenkranz RA, Tyson JE, McDonald SA, Donovan EF, et al. Whole-body hypothermia for neonates with hypoxic-ischemic encephalopathy. N Engl J Med [Internet]. 2005 Oct 13 [cited 2012 Nov 27];353(15):1574-84. Available from: http://www.ncbi.nlm.nih.gov/pubmed/16221780 12. Varon J, Sternbach GL. Cardiopulmonary resuscitation: lessons from the past. J Emerg Med [Internet]. [cited 2013 Jan 26];9(6):503-7. Available from: http://www.ncbi.nlm.nih.gov/pubmed/1787299

13. Alzaga AG, Cerdan M, Varon J. Therapeutic hypothermia. Resuscitation [Internet]. 2006 Sep [cited 2012 Oct 26];70(3):369-80. Available from: http://www.ncbi.nlm.nih.gov/pubmed/16930801 
DOI: 10.2478/romneu-2014-0035

14. Polderman KH. Induced hypothermia and fever control for prevention and treatment of neurological injuries. Lancet [Internet]. 2008 Jun 7 [cited 2013 Jan 27];371(9628):1955-69. Available from: http://www.ncbi.nlm.nih.gov/pubmed/18539227

15. Tokutomi T, Morimoto K, Miyagi T, Yamaguchi S, Ishikawa K, Shigemori M. Optimal temperature for the management of severe traumatic brain injury: effect of hypothermia on intracranial pressure, systemic and intracranial hemodynamics, and metabolism. Neurosurgery [Internet]. 2007 Jul [cited 2013 Jan 26];61(1 Suppl):256-65; discussion 265-6. Available from: http://www.ncbi.nlm.nih.gov/pubmed/18813163

16. Hachimi-Idrissi S, Huyghens L. Therapeutic hypothermia after traumatic brain injury in children: to cool or not to cool? Resuscitation [Internet]. $2008 \mathrm{Nov}$ [cited 2012 Nov 27];79(2):185-6. Available from: http://www.ncbi.nlm.nih.gov/pubmed/18951112

17. Christian E, Zada G, Sung G, Giannotta SL. A review of selective hypothermia in the management of traumatic brain injury. Neurosurg Focus [Internet]. 2008 Oct [cited 2012 Oct 29];25(4):E9. Available from: http://www.ncbi.nlm.nih.gov/pubmed/18828707

18. Abate MG, Cadore B, Citerio G. Hypothermia in adult neurocritical patients: a very hot" strategy not to be hibernated yet! Minerva Anestesiol [Internet]. 2008 [cited 2013 Jan 26];74(7-8):425-30. Available from: http://www.ncbi.nlm.nih.gov/pubmed/18356803

19. Clifton GL. Is keeping cool still hot? An update on hypothermia in brain injury. Curr Opin Crit Care [Internet]. 2004 Apr [cited 2013 Jan 26];10(2):116-9. Available from: http://www.ncbi.nlm.nih.gov/pubmed/15075721

20. Honeybul S, Ho K, Lind C, Gillett G. Hypothermia in patients with brain injury: the way forward? Lancet Neurol [Internet]. 2011 May [cited 2013 Jan 26];10(5):405-6; author reply 406-7. Available from: http://www.ncbi.nlm.nih.gov/pubmed/21511192

21. Lee H-C, Chuang H-C, Cho D-Y, Cheng K-F, Lin P$\mathrm{H}$, Chen C-C. Applying cerebral hypothermia and brain oxygen monitoring in treating severe traumatic brain injury. World Neurosurg [Internet]. 2010 Dec [cited 2012 Nov 12];74(6):654-60. Available from: http://www.ncbi.nlm.nih.gov/pubmed/21492636 22. Nichol AD, Trapani T, Murray L, Vallance S, Cooper DJ. Hypothermia in patients with brain injury: the way forward? Lancet Neurol [Internet]. 2011 May [cited 2013
Jan 26];10(5):405; author reply 406-7. Available from: http://www.ncbi.nlm.nih.gov/pubmed/21511193

23. Polderman KH, Andrews PJD. Hypothermia in patients with brain injury: the way forward? Lancet Neurol [Internet]. 2011 May [cited 2012 Dec 19];10(5):404-5; author reply 406-7. Available from: http://www.ncbi.nlm.nih.gov/pubmed/21511190

24. Potapov A. Applying cerebral hypothermia and brain oxygen monitoring in treating severe traumatic brain injury: a preliminary study. World Neurosurg [Internet]. 2010 [cited 2013 Jan 26];74(2-3):259-60. Available from: http://www.ncbi.nlm.nih.gov/pubmed/21492551

25. Schibler A, Humphreys S. Increased brain tissue oxygen tension in children with traumatic brain injury using temperature-corrected guided ventilation during prophylactic hypothermia. Crit Care Resusc [Internet]. 2012 Mar [cited 2013 Jan 26];14(1):20-4. Available from: http://www.ncbi.nlm.nih.gov/pubmed/22404057

26. Takeuchi S, Nawashiro H, Otani N. Hypothermia in patients with brain injury: the way forward? Lancet Neurol [Internet]. 2011 May [cited 2013 Jan 26];10(5):404; author reply 406-7. Available from: http://www.ncbi.nlm.nih.gov/pubmed/21511191

27. Rubiano AM, Sanchez AI, Estebanez G, Peitzman A, Sperry J, Puyana JC. The effect of admission spontaneous hypothermia on patients with severe traumatic brain injury. Injury [Internet]. 2012 Dec 27 [cited 2013 Jan 26]; Available from: http://www.ncbi.nlm.nih.gov/pubmed/23273319 28. Bigler ED, Maxwell WL. Neuroimaging and neuropathology of TBI. NeuroRehabilitation [Internet]. 2011 Jan [cited 2013 Jan 26];28(2):63-74. Available from: http://www.ncbi.nlm.nih.gov/pubmed/21447905

29. Bramlett HM, Dietrich WD. Pathophysiology of cerebral ischemia and brain trauma: similarities and differences. J Cereb Blood Flow Metab [Internet]. 2004 Mar [cited 2012 Nov 30];24(2):133-50. Available from: http://www.ncbi.nlm.nih.gov/pubmed/14747740

30. Maas AIR, Roozenbeek B, Manley GT. Clinical trials in traumatic brain injury: past experience and current developments. Neurotherapeutics [Internet]. 2010 Jan [cited 2013 Jan 21];7(1):115-26. Available from: http://www.ncbi.nlm.nih.gov/pubmed/20129503 31. Part 7.5: Postresuscitation Support. Circ [Internet]. 2005 Dec 13;112 (24 suppl ):IV-84-IV-88. Available from: 
http://circ.ahajournals.org/content/112/24_suppl/IV84.short

32. Jiang J-Y, Xu W, Li W-P, Gao G-Y, Bao Y-H, Liang Y$M$, et al. Effect of long-term mild hypothermia or shortterm mild hypothermia on outcome of patients with severe traumatic brain injury. J Cereb Blood Flow Metab [Internet]. 2006 Jun [cited 2012 Nov 7];26(6):771-6. Available

from:

http://www.ncbi.nlm.nih.gov/pubmed/16306933

33. Suehiro E, Fujisawa H, Koizumi H, Yoneda $H$, Ishihara $\mathrm{H}$, Nomura $\mathrm{S}$, et al. Survey of current neurotrauma treatment practice in Japan. World Neurosurg [Internet]. [cited 2012 Nov 21];75(3-4):563-8. Available from: http://www.ncbi.nlm.nih.gov/pubmed/21600513 34. Osler W. The cold-bath treatment of Typhoid fever. Medical News Philadelphia. 1892;

35. Cushing J. Memoirs of Military Surgery, and Campaigns of the French Armies, on the Rhine, in Corsica, Catalonia, Egypt, and Syria; at Boulogne, Ulm, and Austerlitz; in Saxony, Prussia, Poland, Spain, and Austria. Memoirs of military surgery and campaigns of the French Armies. Baltimore; 1814. p. 156-64.

36. Fay T. Observations on prolongued human refrigeration. N Y St J Med. 1940;40:1351-4.

37. Fay T. Observations on generalized refrigeration in cases of severe cerebral trauma. Assoc Res Nerv Ment Dis Proc. 1943;24:611-9.

38. Tierney E. The Nazi hypothermia experiments: forbidden data? Anaesthesia [Internet]. 2005 Apr [cited 2013 Jan 30];60(4):413. Available from: http://www.ncbi.nlm.nih.gov/pubmed/15766350

39. Post SG. The echo of Nuremberg: Nazi data and ethics. J Med Ethics [Internet]. 1991 Mar [cited 2013 Jan 30];17(1):42-4. Available from: http://www.pubmedcentral.nih.gov/articlerender.fcgi?ar tid $=1375971 \&$ tool $=$ pmcentrez\&rendertype $=$ abstract 40. Pozos R. Nazi hypothermia research: Should the data be used? Military medical ethics. p. 437-61.

41. Bigelow WG, Callaghan JC, Hopps JA. General hypothermia for experimental intracardiac surgery; the use of electrophrenic respirations, an artificial pacemaker for cardiac standstill and radio-frequency rewarming in general hypothermia. Ann Surg [Internet]. 1950 Sep [cited 2013 Jan 30];132(3):531-9. Available from: http://www.pubmedcentral.nih.gov/articlerender.fcgi?ar tid $=1616776 \&$ tool $=$ pmcentrez\&rendertype $=$ abstract
42. Clifton GL, Valadka A, Zygun D, Coffey CS, Drever P, Fourwinds $\mathrm{S}$, et al. Very early hypothermia induction in patients with severe brain injury (the National Acute Brain Injury Study: Hypothermia II): a randomised trial. Lancet Neurol [Internet]. 2011 Feb [cited 2012 Nov 5];10(2):131-9. Available from: http://www.ncbi.nlm.nih.gov/pubmed/21169065 43. Dietrich WD, Atkins CM, Bramlett HM. Protection in animal models of brain and spinal cord injury with mild to moderate hypothermia. J Neurotrauma [Internet]. 2009 Mar [cited 2012 Nov 27];26(3):301-12. Available from:

http://www.pubmedcentral.nih.gov/articlerender.fcgi?ar tid $=2848835 \&$ tool $=$ pmcentrez\&rendertype $=$ abstract 44. Bratton SL, Chestnut RM, Ghajar J, McConnell Hammond FF, Harris OA, Hartl R, et al. Guidelines for the management of severe traumatic brain injury. II. Hyperosmolar therapy. J Neurotrauma [Internet]. 2007 Jan [cited 2012 Oct 29];24 Suppl 1:S14-20. Available from: http://www.ncbi.nlm.nih.gov/pubmed/17511539 45. Dietrich WD, Bramlett HM. The evidence for hypothermia as a neuroprotectant in traumatic brain injury. Neurotherapeutics [Internet]. 2010 Jan [cited 2012 Dec 11];7(1):43-50. Available from: http://www.pubmedcentral.nih.gov/articlerender.fcgi?ar tid $=2819078 \&$ tool $=$ pmcentrez\&rendertype $=$ abstract 46. Qiu W, Zhang Y, Sheng H, Zhang J, Wang W, Liu W, et al. Effects of therapeutic mild hypothermia on patients with severe traumatic brain injury after craniotomy. J Crit Care [Internet]. 2007 Sep [cited 2012 Dec 11];22(3):229$35 . \quad$ Available from: http://www.ncbi.nlm.nih.gov/pubmed/17869973 47. Polderman KH. Mechanisms of action, physiological effects, and complications of hypothermia. Crit Care Med [Internet]. 2009 Jul [cited 2013 Jan 30];37(7 Suppl):S186$202 . \quad$ Available from: http://www.ncbi.nlm.nih.gov/pubmed/19535947 48. Moore EM, Nichol AD, Bernard SA, Bellomo R. Therapeutic hypothermia: benefits, mechanisms and potential clinical applications in neurological, cardiac and kidney injury. Injury [Internet]. $2011 \mathrm{Sep}$ [cited $2012 \mathrm{Nov}$ 13];42(9):843-54. Available from: http://www.ncbi.nlm.nih.gov/pubmed/21481385 49. Wang GJ, Deng HY, Maier CM, Sun GH, Yenari MA. Mild hypothermia reduces ICAM-1 expression, neutrophil infiltration and microglia/monocyte accumulation following experimental stroke. 
DOI: 10.2478/romneu-2014-0035

Neuroscience [Internet]. 2002 Jan [cited 2013 Jan 26];114(4):1081-90. Available from: http://www.ncbi.nlm.nih.gov/pubmed/12379261 50. Jiang J-Y, Xu W, Yang P-F, Gao G-Y, Gao Y-G, Liang $\mathrm{Y}-\mathrm{M}$, et al. Marked protection by selective cerebral profound hypothermia after complete cerebral ischemia in primates. J Neurotrauma [Internet]. 2006 Dec [cited 2013 Jan 26];23(12):1847-56. Available from: http://www.ncbi.nlm.nih.gov/pubmed/17184193

51. Ehrlich MP, McCullough JN, Zhang N, Weisz DJ, Juvonen T, Bodian CA, et al. Effect of hypothermia on cerebral blood flow and metabolism in the pig. Ann Thorac Surg [Internet]. 2002 Jan [cited 2013 Jan 26];73(1):191-7. Available from: http://www.ncbi.nlm.nih.gov/pubmed/11834009

52. Maier CM, Sun GH, Cheng D, Yenari MA, Chan PH, Steinberg GK. Effects of mild hypothermia on superoxide anion production, superoxide dismutase expression, and activity following transient focal cerebral ischemia. Neurobiol Dis [Internet]. 2002 Oct [cited 2013 Jan 26];11(1):28-42. Available from: http://www.ncbi.nlm.nih.gov/pubmed/12460544

53. Polderman KH, Herold I. Therapeutic hypothermia and controlled normothermia in the intensive care unit: practical considerations, side effects, and cooling methods. Crit Care Med [Internet]. 2009 Mar [cited 2012 Oct 25];37(3):1101-20. Available from: http://www.ncbi.nlm.nih.gov/pubmed/19237924

54. Van den Broek MPH, Groenendaal F, Egberts ACG, Rademaker CMA. Effects of hypothermia on pharmacokinetics and pharmacodynamics: a systematic review of preclinical and clinical studies. Clin Pharmacokinet [Internet]. 2010 May [cited 2013 Jan 26];49(5):277-94. Available from: http://www.ncbi.nlm.nih.gov/pubmed/20384391

55. Busto R, Dietrich WD, Globus MY, Valdés I, Scheinberg P, Ginsberg MD. Small differences in intraischemic brain temperature critically determine the extent of ischemic neuronal injury. J Cereb Blood Flow Metab [Internet]. 1987 Dec [cited 2013 Jan 29];7(6):729$38 . \quad$ Available from: http://www.ncbi.nlm.nih.gov/pubmed/3693428

56. Dietrich WD, Alonso O, Halley M, Busto R. Delayed posttraumatic brain hyperthermia worsens outcome after fluid percussion brain injury: a light and electron microscopic study in rats. Neurosurgery [Internet]. 1996
Mar [cited 2013 Jan 29];38(3):533-41; discussion 541. Available from:

http://www.ncbi.nlm.nih.gov/pubmed/8837806

57. Childs C, Vail A, Leach P, Rainey T, Protheroe R, King A. Brain temperature and outcome after severe traumatic brain injury. Neurocrit Care [Internet]. 2006 Jan [cited 2013 Jan 29];5(1):10-4. Available from: http://www.ncbi.nlm.nih.gov/pubmed/16960288 58. Wang Q, Li A, Zhi D, Huang H. Effect of mild hypothermia on glucose metabolism and glycerol of brain tissue in patients with severe traumatic brain injury. Chin J Traumatol [Internet]. 2007 Aug [cited 2013 Jan 29];10(4):246-9. Available from: http://www.ncbi.nlm.nih.gov/pubmed/17651596 59. Spiotta AM, Stiefel MF, Heuer GG, Bloom S, Maloney-Wilensky E, Yang W, et al. Brain hyperthermia after traumatic brain injury does not reduce brain oxygen. Neurosurgery [Internet]. 2008 Apr [cited 2013 Jan 29];62(4):864-72; discussion 872. Available from: http://www.ncbi.nlm.nih.gov/pubmed/18414135

60. Sakurai A, Atkins CM, Alonso OF, Bramlett HM, Dietrich WD. Mild hyperthermia worsens the neuropathological damage associated with mild traumatic brain injury in rats. J Neurotrauma [Internet]. 2012 Jan 20 [cited 2013 Jan 29];29(2):313-21. Available from:

http://www.pubmedcentral.nih.gov/articlerender.fcgi?ar tid $=3261791$ \&tool $=$ pmcentrez\&rendertype $=$ abstract

61. Curry P, Viernes D, Sharma D. Perioperative management of traumatic brain injury. Int J Crit Illn Inj Sci [Internet]. 2011 Jan [cited 2012 Nov 6];1(1):27-35. Available from:

http://www.pubmedcentral.nih.gov/articlerender.fcgi?ar tid=3209993\&tool=pmcentrez\&rendertype $=$ abstract

62. Dietrich WD. Therapeutic hypothermia for acute severe spinal cord injury: ready to start large clinical trials?. Crit Care Med [Internet]. 2012 Mar [cited 2013 Jan 29];40(2):691-2. Available from: http://www.ncbi.nlm.nih.gov/pubmed/22249057 63. Tomura S, de Rivero Vaccari JP, Keane RW, Bramlett HM, Dietrich WD. Effects of therapeutic hypothermia on inflammasome signaling after traumatic brain injury. J Cereb Blood Flow Metab [Internet]. 2012 Oct [cited 2013 Jan 29];32(10):1939-47. Available from: http://www.ncbi.nlm.nih.gov/pubmed/22781337

64. Harris OA, Colford JM, Good MC, Matz PG. The role of hypothermia in the management of severe brain injury: 
a meta-analysis. Arch Neurol [Internet]. 2002 Jul [cited 2013 Jan 27];59(7):1077-83. Available from: http://www.ncbi.nlm.nih.gov/pubmed/12117354 65. Clifton GL, Miller ER, Choi SC, Levin HS, McCauley $S$, Smith KR, et al. Lack of effect of induction of hypothermia after acute brain injury. N Engl J Med [Internet]. 2001 Feb 22 [cited 2013 Jan 26];344(8):556-63. Available from: http://www.ncbi.nlm.nih.gov/pubmed/11207351 66. Polderman KH. Application of therapeutic hypothermia in the ICU: opportunities and pitfalls of a promising treatment modality. Part 1: Indications and evidence. Intensive Care Med [Internet]. 2004 Apr [cited 2012 Oct 26];30(4):556-75. Available from: http://www.ncbi.nlm.nih.gov/pubmed/14767591

67. Peterson K, Carson S, Carney N. Hypothermia treatment for traumatic brain injury: a systematic review and meta-analysis. J Neurotrauma [Internet]. 2008 Jan [cited 2012 Oct 28];25(1):62-71. Available from: http://www.ncbi.nlm.nih.gov/pubmed/18355159 68. Hutchison JS, Ward RE, Lacroix J, Hébert PC, Barnes MA, Bohn DJ, et al. Hypothermia therapy after traumatic brain injury in children. N Engl J Med [Internet]. 2008 Jun 5 [cited 2013 Jan 27];358(23):2447-56. Available from: http://www.ncbi.nlm.nih.gov/pubmed/18525042 69. Harris OA, Muh CR, Surles MC, Pan Y, Rozycki G, Macleod J, et al. Discrete cerebral hypothermia in the management of traumatic brain injury: a randomized controlled trial. J Neurosurg [Internet]. 2009 Jun [cited 2012 Nov 29];110(6):1256-64. Available from: http://www.ncbi.nlm.nih.gov/pubmed/19249933
70. Sahuquillo J, Vilalta A. Cooling the injured brain: how does moderate hypothermia influence the pathophysiology of traumatic brain injury. Curr Pharm Des [Internet]. 2007 Jan [cited 2013 Jan 27];13(22):231022. Available from: http://www.ncbi.nlm.nih.gov/pubmed/17692002

71. Gal R, Cundrle I, Zimova I, Smrcka M. Mild hypothermia therapy for patients with severe brain injury. Clin Neurol Neurosurg [Internet]. 2002 Sep [cited 2013 Jan 27];104(4):318-21. Available from: http://www.ncbi.nlm.nih.gov/pubmed/12140097

72. Lavinio A, Timofeev I, Nortje J, Outtrim J, Smielewski P, Gupta A, et al. Cerebrovascular reactivity during hypothermia and rewarming. $\mathrm{Br} \mathrm{J}$ Anaesth [Internet]. 2007 Aug [cited 2012 Nov 22];99(2):237-44. Available from: http://www.ncbi.nlm.nih.gov/pubmed/17510046 73. Georgiou AP, Manara AR. Role of therapeutic hypothermia in improving outcome after traumatic brain injury: a systematic review. Br J Anaesth [Internet]. 2013 Jan 25 [cited 2013 Jan 29]; Available from: http://www.ncbi.nlm.nih.gov/pubmed/23353036 74. Andrews PJD, Sinclair HL, Battison CG, Polderman $\mathrm{KH}$, Citerio G, Mascia L, et al. European society of intensive care medicine study of therapeutic hypothermia $\left(32-35{ }^{\circ} \mathrm{C}\right)$ for intracranial pressure reduction after traumatic brain injury (the Eurotherm3235Trial). Trials [Internet]. 2011 Jan [cited 2013 Jan 29];12:8. Available from:

http://www.pubmedcentral.nih.gov/articlerender.fcgi?ar tid $=3027122 \&$ tool $=$ pmcentrez\&rendertype $=$ abstract 